University of Nebraska - Lincoln

DigitalCommons@University of Nebraska - Lincoln

USDA National Wildlife Research Center - Staff Publications
U.S. Department of Agriculture: Animal and Plant Health Inspection Service

January 2005

\title{
Foraging Behavior and Monetary Impact of Wading Birds at Arkansas Baitfish Farms
}

Scott J. Werner

USDA-APHIS-Wildlife Services, scott.j.werner@aphis.usda.gov

J. Brett Harrel

United States Department of Agriculture, Animal and Plant Health Inspection Service, Wildlife Services, National Wildlife Research Center

David E. Wooten

United States Department of Agriculture, Agricultural Research Service, H.K. Dupree National Aquaculture Research Center

Follow this and additional works at: https://digitalcommons.unl.edu/icwdm_usdanwrc

Part of the Environmental Sciences Commons

Werner, Scott J.; Harrel, J. Brett; and Wooten, David E., "Foraging Behavior and Monetary Impact of Wading Birds at Arkansas Baitfish Farms" (2005). USDA National Wildlife Research Center - Staff Publications. 69. https://digitalcommons.unl.edu/icwdm_usdanwrc/69

This Article is brought to you for free and open access by the U.S. Department of Agriculture: Animal and Plant Health Inspection Service at DigitalCommons@University of Nebraska - Lincoln. It has been accepted for inclusion in USDA National Wildlife Research Center - Staff Publications by an authorized administrator of DigitalCommons@University of Nebraska - Lincoln. 


\title{
Foraging Behavior and Monetary Impact of Wading Birds at Arkansas Baitfish Farms
}

\author{
SCOTT J. Werneri \\ United Siates Department of Agriculture. Agricultural Research Service. H.K. Dupree National Aquaculture

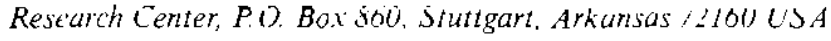 \\ J. BRENT HARREL 2 \\ Lnited States Deparment of Agriculture, Animal and Plant He'alh Inspection Servite. Wildlife Services. \\ National Wildlife Research Center. Mississippi Field Station. P. O. Drawer 6099. Mississippi State Lniversity; \\ Mississippi 39762 LSA \\ David E. WoOten ${ }^{3}$ \\ United States Department of Agriculture, Agricultural Research Service. H. K. Dupree National Aquaculture \\ Reseatich Center, P.O. Box 860. Stuttgart, Arkansas 72160 LSA
}

\begin{abstract}
We randucted foraging observations, food habits studies, and producer surveys to deternine the foraging behavior and monetary impact of great blue herons Ardea herodias, great egrets A. alba, and little blue herons Egretta caerulea foraging at Arkansas baitfish farms. Although great egrets captured most baitfish/minute, captures/strike were nearly identical among the three wading bird species. American gizzard shad Dorosoma cepedianum, goldfish Carassius auratus, and giant water bugs Hemiptera: Belostomatidae were collected from the gastro-intestinal tract of great blue herons. Only golden shiners Notemigonus crysoleucas and goldfish were found in great egrets. We found dragonflies Odonata, golden shiners, green sunfish Lepomis cyanellus, and water bugs in little blue herons. In contrast to other birds collected, snowy egrets $E$. thula were found to contain mosquito fish Gambusia affinis. Among 2,742 teleost otoliths recovered from collected great blue herons, great egrets, and little biue herons, most otoliths belonged to the Cyprinidae family (including the baitfishes). Surveyed farm managers use various auditory and visual stimuli to disperse fish-eating birds from their farms. Surveyed baitfish farmers suggested that the average cost of their annual bird harassment program was $\$ 11,580$ at relatively small farms $(<202$ ha) and $\$ 104,560$ at relatively large $(\geq 202 \mathrm{ha}$ ) baitfish aquaculture facilities. We estimated the replacemeut cost of baitfish consumed by wading birds based upon their daily food requirements, the food habits of herons and egrets at baitfish farms, the hypothetical abundance of wading birds at a particular baitfish farm (relative to survey results), the duration of herons and egrets reported by farm managers, and current baitfish market values.
\end{abstract}

Aquaculture in the United States presently involves over 4,000 individual farms, with total sales exceeding $\$ 975$ million/yr (USDA

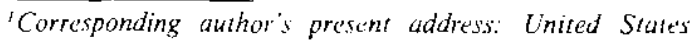
Department of Agricullure, Animal and Plant Healh Inspection Service. Wildlife Services, National Wildlife Research Center, 4101 LaPorte Avenue. Fort Collins. Colorado 80521-2154 USA.

'Present address: L'nired States Fish und Wildife Service. Kentucky' Fitd Office. 3761 Georgetown Roud. Frankfort, Kentucky 40601 LS.A

${ }^{3}$ Present address: Unired States Deparment of Interior. Bureau of Indian Affairs. Pucific Re'gional Office-Branch of Forestry, 2800 Cottage thay Sacramento, California 05825 LS.A.
2000). According to this 1998 census, the two states with greatest aquaculture sales are Mississippi ( $\$ 290$ million of catfish) and Arkansas ( $\$ 84$ million of catfish and baitfish). Although baitfish are cultured throughout Arkansas, the production of golden shiners Notemig(-) nus crysoleucas, goldfish Carassius auratus. and fathead minnows Pimephales promelas is primarily located in central Arkansas, east of Little Rock (Lonoke and Prairie counties). In 1980 , approximately 6,400 ha were used for baitfish production in Arkansas $83 \%$ golden shiners, $10 \%$ fathead minnows. $7 \%$ goldfish). By 1995, the Arkansas baitfish industry had 
grown to approximately 12,100 ha $(64 \%$ golden shiners, $16 \%$ fathead minnows. $20 \%$ goldfish: N. Stone, University of Arkansas-Pine Bluff. unpublished data). Approximately 48 and 16\% of these Arkansas baitfish farms are located in Lonoke and Prairie counlies, respectively (C. Collins, USDA/ARS/H.K. Dupree National Aquaculture Research Center, unpublished data).

North American aquaculture facilities provide potential inland foraging sites for many species of fish-eating birds. Much research has focused on the impacts of double-crested cormorants Phalucrocorax auritus (Stickley et al. 1992; Glahn and Brugger 1995; Glahn and Stickley 1995; Glahn and Dorr 2002), great blue herons Ardea herodius (Ross 1994; Stickley et al. 1995; Glahn et al. 1999b, 2000, 2002), Anterican white pelicans Pelecanus erythrorlwnchos (King and Werner 2001; King and Michot 2002), and great egrets $A$. alba (Ross 1994; Glahn et al. 1999b; Werner et al. 2001) to catfish aquaculture. Although the food habits of diving ducks at baitfish aquaculture facilities have been recently investigated (Wooten and Werner 2004), few studies have addressed the foraging ecology of herons and egrets associated with baitfish production (Hoy et al. 1989; Hoy 1994).

The overall monetary impact of bird depredation includes the cost of replacing consumed baitfish and the cost of harassing fish-eating birds. The development of cost-effective management strategies is contingent upon reconciling these costs with resultant baitfish production. The objectives of this study were to investigate the foraging behavior and monetary impacts of herons and egrets at baitfish aquaculture facilities in Arkansas.

\section{Materials and Methods}

\section{Foraging Observations}

We conducted foraging observations from 18 August until 1 September 1999 on seven baitfish farms in Lonoke and Prairie counties. Observations were conducted from $30-210 \mathrm{~min}$ following sunrise. Three observers watched and recorded all foraging behavior of great blue herons (observed among $4 \mathrm{~d}$ and five farms), great egrets ( $5 \mathrm{~d}$, five farms), and little blue herons Egretta caerulea ( $6 \mathrm{~d}$, four farms). Using binoculars and spotting scopes. observers recorded the date, farm name. species, bird age (immature, adult, unknown [based on plumage and bare parts!: Palmer 19/6, Vorsin 1991), number of fish captures, number of strikes, foragiug time $( \pm 1 \mathrm{~min}$ ), and whether birds were disturbed (by farm workers via fish feeding and/or bird harassment) during each foraging observation. Observation data were summarized to estimate average captures/strike, strikes/min, and captures/min for each wading bird species. We estimated the average time of foraging bouts and captures/foraging bout using only foraging observations that were not terminated by disturbance.

\section{Gut Analvies}

We used .22-250 rifles and 12-gauge shotguns (\#2 steel shot) to opportunistically collect 30 great blue herons (collected among 5 $\mathrm{d}$ and seven farms), 34 great egrets (4 d, seven farms), and 29 little blue herons ( $5 \mathrm{~d}$, six farms) for $3 \mathrm{~h}$ subsequent to foraging observations and tor three hours prior to sunset. Seven snowy egrets Egretta thuld were also collected (on three farms) to determine diet breadth. For the purpose of food habits studies associated with aquacultural production, only birds in ponds or at the edge of ponds were collected.

We recorded the date, farm name, time, and the bird species, age (Palmer 1976), gender (based on post-mortem, internal examination), and body mass $( \pm 1 \mathrm{~g}$ ) immediately following each bird collection. The esophagus, ventriculus, and lower gastro-intestinal track were removed from each bird and stored on ice in a labeled plastic bag for subsequent laboratory analyses. For all specimens, we macroscopically identified, measured $( \pm 1 \mathrm{~mm}$ ), and weighed ( \pm $0.1 \mathrm{~g}$ ) all discernable prey items following procedures similar to Glahn et al. (1995, 1999a). Brass testing sieves (U.S. Standard \#30, 60; 0.60 and $0.25-\mathrm{mm}$ opening, respectively) were used to isolate prey items from undifferentiated gut contents.

When advanced digestion precluded an ac- 
curate (whole-fish) mass estimate, we applied species-specific, length-to-weight regression equations (Carlander 1969) to our fish length data to predict the mass of observed prey items. A tail length-to-overall length regression (J. F. Glahn, USDA/APHIS/WS/ National Wildlife Research Center, unpublished data) was used to predict the overall length of a well-digested American gizzard shad Dorosoma cepedianum prior to predicting its weight. We used descriptive statistics (mean \pm SEM) to evaluate the percent of discernable prey items, and the length and mass of discernable prey items recovered during gut analyses.

\section{Otolith Analyses}

To supplement our food habits analysis, teleost otoliths were secured from the ventriculus and lower gastro-intestinal tract of all collected birds, and preserved for subsequent microscopic identification. Otoliths were identified by fish family using methods described by Glahn et al. (1999a) and Harrel and Stringer (1997). Given varied erosion among recovered otoliths, we did not predict fish length or age from recovered otoliths. When more than one otolith type (astericus, lapillae, sagittae) from a particular fish family was recovered from a single gut, only data from the type occurring in highest abundance were used for subsequent analyses to minimize the re-count of ingested fish.

\section{Producer Surveys and Baitfish Replacement Costs}

From 3 August until 27 August 1999, we visited baitfish aquaculture facilities in Arkansas to conduct personal interviews with farm managers. Surveys were conducted in Chicot, Drew, Lonoke, Monroe, Poinsett, Prairie, and St. Francis counties. The number of surveys conducted in each county was based upon the proportion of baitfish farms/ county and the availability of farm managers that agreed to be interviewed. Thirty-three percent of known baitfish farms in Arkansas $(N=95$; C. Collins, USDA/ARS/H.K. Dupree National Aquaculture Research Center, unpublished data) were included in our survey. We asked each farmer a series of questions regarding: 1) the primary negative im- pacts to their fish production (ranked highest to lowest); 2) their particular farm operation (area and cultured species); 3) their primary avian predators (species [ranked based on perceived impacts], timing and duration of occurrence, and abundance); and 4) the conlrol measures (with associated monetary costs) used to minimize bird depredation at their aquaculture facility.

We used the following regression model developed by Kushlan (1978) to predict the daily food requirements $(\mathrm{g} / \mathrm{d})$ of herons and egrets: $\log y=0.966 \log x-0.640$, where $x$ is the average body mass $(\mathrm{g})$ of collected wading birds. We calculated the mass "per baitfish" in the diet of our collected birds by multiplying the average mass $(\mathrm{g})$ of discernable fish (by species) in the gut of collected birds by the average proportion of Cyprinid fishes in these guts. We then calculated the mass of baitfish consumed per foraging bout by multiplying the number of fish ingested during foraging observations by the mass "per baitfish." We divided the predicted daily food requirement by the mass of baitfish consumed per foraging bout to determine the number of foraging bouts needed to meet the daily food requirements of herons and egrets.

We calculated the replacement cost of baitfish consumed by wading birds by multiplying the following variables by relatively high $(\$ 1.8 / \mathrm{kg}$, or $\$ 4 / \mathrm{lb})$ and low $(\$ 1.4 / \mathrm{kg}$, or $\$ 3 / \mathrm{lb})$ baitfish prices $(\mathrm{H}$. Thomforde, University of Arkansas-Pine Bluff, personal communication): mass consumed per foraging bout, foraging bouts/day, hypothetical bird abundance, and the number of days associated with wading bird presence at Arkansas baitfish farms (from survey results). The SEM of fish mass consumed per foraging bout was used to estimate baitfish replacement costs. Bird abundance estimates were further based upon those reported by Hoy (1994) for little blue herons, great blue herons, great egrets, and snowy egrets observed at Arkansas baitfish farms in June through August (100-200 birds/facility) and in September (500-5,000 birds/facility; Hoy 1994). 
TARLE 1. Foraging behavior of waling birds near Arkansas baitfish farms.

\begin{tabular}{lccc}
\hline & Great biue herons & Great egrets & Little blue herons \\
\hline Observed strikes/foraging bout & $30.7 \pm 5.11$ & $26.5 \pm 11.31$ & $17.8 \pm 4.74$ \\
Observed captures/foraging bout & $22.5 \pm 12.09$ & $14.3 \pm 6.57$ & $11.2 \pm 3.40$ \\
Captures/strike/foraging bout & $0.6 \pm 0.10$ & $0.6 \pm 0.10$ & $0.6 \pm 0.04$ \\
$N$ & 11 & 12 & 50 \\
Strikes/min & $0.9 \pm 0.30$ & $1.9 \pm 0.57$ & $1.6 \pm 0.20$ \\
$N$ & 11 & 12 & 50 \\
Captures/min & $0.6 \pm 0.25$ & $1.1 \pm 0.39$ & $1.0 \pm 0.13$ \\
$N$ & 11 & 12 & 58 \\
Min/undisturbed foraging bout & 25.4 & 15.7 & 10.0 \\
$N$ & 7 & $17.3 \pm 6.12$ & 18 \\
Captures/undisturbed foraging bout & $15.2 \pm 6.35$ & & $9.6 \pm 1.26$ \\
\hline
\end{tabular}

\section{Results}

\section{Foraging Observations}

Our foraging observations included 58 little blue herons that foraged for a total of $601 \mathrm{~min}$, 11 great blue herons ( $266 \mathrm{~min}$ ), and 12 great egrets $(144 \mathrm{~min})$. Fish captures/strike were nearly identical among the three wading birds observed (Table 1). Thus, great blue herons apparently captured more fish by initiating more strikes toward baitfish. The duration of foraging bouts was also longer for great blue herons than that for great egrets and little blue herons. Of all herons and egrets observed, great egrets captured most baitfish/min and they exhibited most captures/foraging observation (Table 1). Compared to little blue herons, great blue herons and great egrets consumed nearly twice as many baitfish/foraging observation.

\section{Gut Analvses}

Of 100 wading birds collected during this study, we collected only five adult great blue herons, one adult great egret, and three adult little blue herons. Thus, $>80 \%$ of wading birds collected at baitfish aquaculture facilities were immature. Forty-three to $79 \%$ of gastro-intestinal tracts from each collected species were empty (i.e., no discernable prey items were found; Table 2). Of birds containing discernable prey, all great blue herons and great egrets contained a single prey species. One little blue heron had four golden shiners and one green sunfish Lepomis cyanellus. In contrast to other collected birds, snowy egrets contained mosquito fish Gambusia affinis (Table 2).

No differences were observed among wading bird species in terms of the average percent of discernable prey recovered during gut analyses (Fig. 1). Among all birds, we found differences among the percentages of various discen nable prey itens in their gastru-inlestinal tracts. We recovered more golden shiners than green sunfish (Fig. 1), and more goldfish than dragonflies (Odonata), American gizzard shad, or green sunfish. We also observed differences among the percentages of particular prey items recovered from individual bird species. No dragonflies, golden shiners, or green sunfish were found in great blue herons (Fig. 1). We found only golden shiners and goldfish in great egrets. No American gizzard shad or goldfish were found in little blue herons.

We observed differences in the average length and predicted weight of various prey items (Table 2). The average length and mass of goldfish found in the guts of collected wading birds were greater than those of golden shiners. We found a single American gizzard shad during our gut analyses. Although the shad was severely digested in the ventriculus of a great blue heron, we estimated that its total length was $70 \mathrm{~mm}$ and its predicted weight was $7.9 \mathrm{~g}$ (Table 2). We observed no differences, however, among bird species in the average length or mass of prey items found in their gastro-intestinal tracts. 
TABI.F. 2. Summary of discernable prey ilems in gastro-intestinal tracts of collected wading birds.

\begin{tabular}{lcccccc}
\hline & GBHE & GREG & LBHE & SNEG & length (mm) & mass (g) \\
\hline$N$ & 30 & 34 & 29 & 7 & & \\
F.mpty gastro-intestinat tract & 22 & 27 & 19 & 3 & & \\
Range of discernable diet items: & & & & & & \\
Dragonflies & 0 & 0 & $0-3$ & 0 & $11 \pm 2.1$ & $1.1 \pm 0.96$ \\
Gizzard shad & $0-1$ & 0 & 0 & 0 & 70 & 7.9 \\
Golden shiners & 0 & $0-9$ & $0-4$ & $0-4$ & $56 \pm 16.0$ & $1.7 \pm 1.35$ \\
Goldfish & $0-4$ & $0-12$ & 0 & 0 & $70 \pm 4.8$ & $12.5 \pm 2.51$ \\
Green sunfish & 0 & 0 & $0-1$ & 0 & 62 & 2.1 \\
Mosquito fish & 0 & 0 & 0 & $2-7$ & $26 \pm 2.3$ & $0.5 \pm 0.32$ \\
Water bugs & $0-2$ & 0 & $0-1$ & 0 & $16 \pm 2.4$ & $0.9 \pm 0.72$ \\
\hline
\end{tabular}

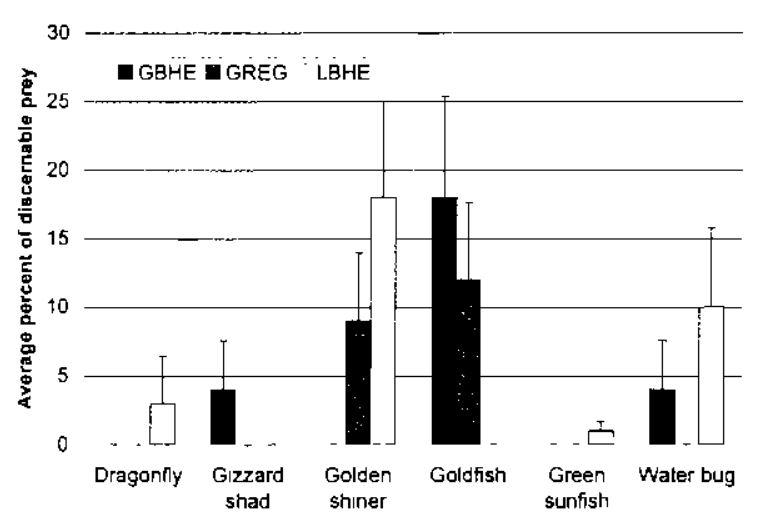

FIGURE I. Average ( $\pm S E M$ ) percemt of discernable prey items found in the gastro-intestinal tract of great blue herons ( $G B H E, N=30$ ). great egrets ( $G R E G, N=$ 34), and little blue herons ( $L B H E, N=29$ ) collected at Arkansas baitfish farms.

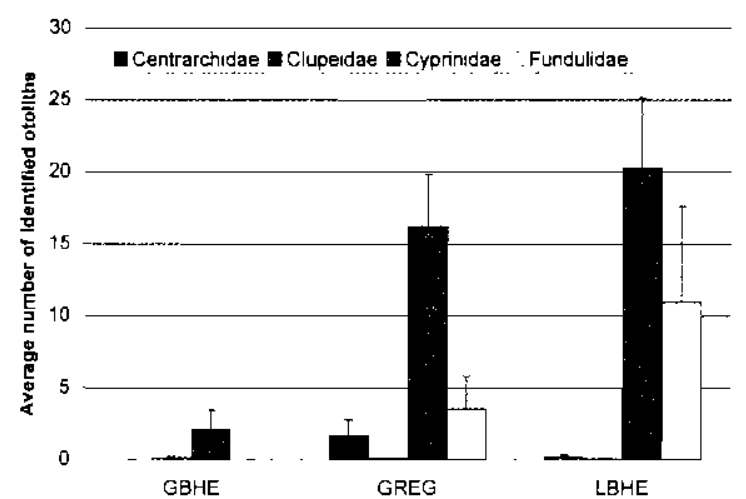

Figure 2. Average ( $\pm S E M)$ number of identified teleost oroliths recovered from the gastro-intestinal tract of great blue herons (GBHE, $\mathrm{N}=30)$, great egrets (GREG, $\mathrm{N}=34$ ), and lithe blue herons ( $L B H E, \mathrm{~N}=$ 29) collected at Arkansas baiffish farms.

\section{Otolith Analyses}

We recovered 2,742 teleost otoliths from the gastro-intestinal tracts of great blue herons, great egrets, and little blue herons. We observed differences in the average number of identified otoliths found among bird species and among fish families (Fig. 2). We recovered the fewest otoliths from great blue herons and most recovered otoliths were from fishes in the Cyprinidae family (including the baitfishes). We found more Cyprinid otoliths in great egrets than other fish families. Among otoliths recovered from little blue herons, we found more otoliths from the Cyprinidae family than those from Centrarchidae and Clupeidae (Fig. 2).

\section{Producer Surveys}

We completed 31 personal interviews with Arkansas baitfish farmers. Twenty farm managers perceived fish-eating birds as their primary negative impact to fish production. These managers reported fish diseases and poor water quality (e.g., low dissolved oxygen, eutrophic conditions, no algal blooms, abundant blue-green algae) as their second and third negative impacts to their aquaculture operation. Fish parasites were also reported as constraints on fish production.

The 31 surveyed farms included approximately 7,725 ha of water surface. On average, farmers reported that approximately $46 \%$ of this area was used to produce golden shiners, and 19\% was used for goldfish aqua- 
culture. Surveyed baitfish farmers also reported their culture of fathead minnows $(\sim 9 \%$ of surveyed farm area), catfish ( $6 \%$ of surveyed farm area), grass carp Ctenopharingodon idellis, and Koi Cyprimus carpio. Although the majority of surveyed farmers ( $53 \%$ ) raise a single fish species, approximately $62 \%$ of surveyed golden shiner producers $(N=21)$ also culture fathead minnows.

Most farmers reported the presence of double-crested cormorants, diving ducks (lesser scaup Aythya affinis, greater scaup $A$, marila. ring-necked ducks $A$. collaris), great blue herons, and "white birds" at their baitfish farms. We observed great egrets and immature little blue herons to account for approximately $30 \%$ and $60 \%$ of "white birds," respectively, at Arkansas baitfish farms during this study. Snowy egrets were also considered in the "white bird" category. On average, farmers reported 100 great blue herons (range $=50-200$ ) on their farms during all months except April, May, and June. "White birds" were reported in groups of 900 birds (approximately 540 little blue herons and 270 great egrets) from June through October, though this report ranged from 100 to 3,000 individuals. Farmers also reported their sightings of flocks of 1,900 double-crested cormorants (range $=25-5,000 ;$ March through April, and September through December) and 7,800 diving ducks (range $=10-100,000$; November through March) at their baitfish farms. At least one farmer also reported their sighting of European starlings Sturnus vu/garis, grackles Quiscalus quiscula, common mergansers $\mathrm{Mer}$ gus mergariser, and American white pelicans at their farms.

When asked about the control measures used to minimize fish-eating bird impacts, farm managers reported using several lethal and/or non-lethal harassment techniques. Most surveyed farmers use pyrotechnics, propane cannons (3-4 d efficacy reported), air horns, and shotguns (4-5 d efficacy reported) to disperse birds from their farms. Most farm managers assign one to ten farm workers to patrol their farm and harass birds when they are most abundant. Orange rice sacks (used as flags), strobe lights, and floating (or standing) scare- crows have also been used, but were reportedly ineffective. One farmer shaded his water with dye to prevent the visual detection of his baitfish by fish-eating birds. Some farmers rotate parked vehicles around their baitfish ponds to prevent birds from landing on ponds. Although most baitfish are sold throughout the year, one farmer reported that he sold most of his fish prior to the arrival of double-crested cormorants. Two farmers mentioned that they keep their highly priced fish near the center of their farm operation to maximize human activity adjacent to ponds.

Among surveyed farm managers, the median size of their farms was 202 ha (i.e., approximately 500 acres; range $=20-1,620$ ha). On average, these farmers reportedly spend $\$ 49,890$ each year to implement bird harassment techniques. This cost (range $=\$ 4,400-\$ 400,000 / y r)$ included pyrotechnics and ammunition costs. and salaries (assumed \$5.15/hour) for farm workers assigned to disperse fish-eating birds. Among farms with $<202$ ha of baitfish production, the average reported cost of their bird harassment program was $\$ 1$ 1,580. Farms with $\leq 202$ ha of baitfish production spend $\$ 104,560$ annually for bird harassment.

\section{Baitfish Replacement Costs}

We estimated the replacement cost of consumed baitfish based on the body mass of great blue herons, great egrets, and little blue herons collected in our study, the average mass and proportion of baitfishes in the gut of collected wading birds, the hypothetical abundance of wading birds at a particular baitfish farm (relative to survey results), the duration of herons and egrets reported by farm managers, the number of fish captured during our foraging observations, and current baitfish market values.

The average body mass of collected great blue herons was $2,369 \mathrm{~g}$ for males $(N=13$, range $=1,950-2,800 \mathrm{~g})$ and $1,927 \mathrm{~g}$ for females $(N=$ 15 , range $=1,500-2,450 \mathrm{~g}$ ). The average mass of great egrets was $1,104 \mathrm{~g}$ for males $(N=12$, range $=950-1,400 \mathrm{~g})$ and $943 \mathrm{~g}$ for females $(N=$ 22 , range $=700-1,200 \mathrm{~g}$ ). The average mass of collected little blue herons was $406 \mathrm{~g}$ for males 


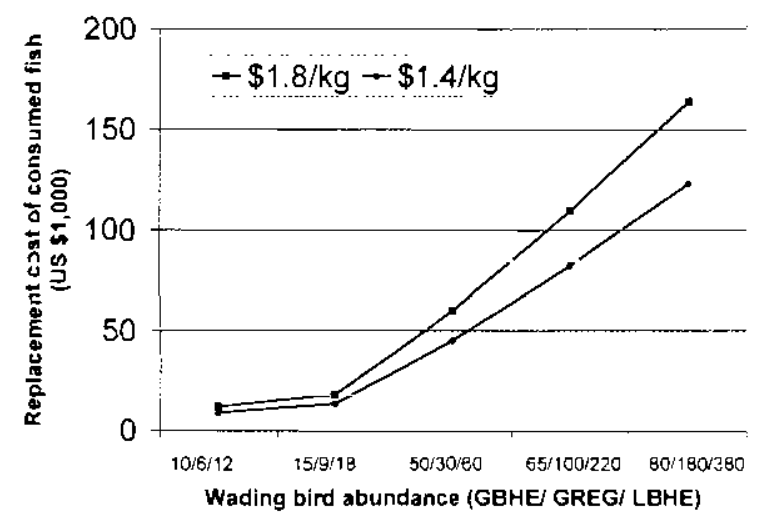

Figure 3. Estimated costs iat high and low baitfish market values) associated with replacing baitfish consumed by wading birds relative to reported costs associated with bird damage managenient at relatively small $(<202 \mathrm{ha})$ and large $(\geq 202 \mathrm{hal}$ baitfish aquaculture facilinies in Arkansas. Hypothetical assenblages of wading bird abundance igreat blue heron, GBHE; great egret, GREG: litlle biue heron (LBHE) were used to predict baitfish replacement costs throughout the range of reported bird numbers and reported damage management expenditures.

$(N=17$, range $=350-500 \mathrm{~g})$ and $392 \mathrm{~g}$ for females $(N=12$, range $=300-460 \mathrm{~g})$. Based on these body masses, and assuming a 50:50 sex ratio in wading bird populations adjacent to Arkansas baitfish farms, we estimated the daily food requirements of great blue herons, great egrets, and little blue herons to be 379,185 , and $75 \mathrm{~g} / \mathrm{d}$, respectively (Kushlan 1978).

The average mass of discernable fish recovered during wading bird gut analyses was I 2.5 $\mathrm{g}$ of goldfish and $1.7 \mathrm{~g}$ of golden shiners. All discernable Cyprinids recovered from great blue herons were goldfish. Among discernable fish found in great egrets, $57 \%$ were goldfish and $43 \%$ were golden shiners. All discernable Cyprinids recovered from little blue herons were golden shiners. We calculated the average mass "per baitfish" found in great blue herons, great egrets, and little blue herons as 12.5, 7.9, and $1.7 \mathrm{~g}$, respectively. Based on these mass data and the number of fish captures/foraging bout (Table 1), we calculated the mass of baitfish consumed/foraging bout to be $190.0 \mathrm{~g}$ for great blue herons, $136.7 \mathrm{~g}$ for great egrets, and $16.3 \mathrm{~g}$ for little blue herons. Based on Kushlan's
(1978) predictions regarding the daily food requirements of wading birds, we estimated that great blue herons forage 2.0 times each day, great egrets forage 1.4 times/d, and little blue herons forage 4.6 times each day at Arkansas baitfish farms.

The replacement cost of baitfish consumed by wading birds (Fig. 3) exceeds the reported cost of bird harassment on relatively small baitfish farms $(<202$ ha) when a combination of 15 great blue herons, nine great egrets, and 18 little blue herons (or more) forage in ponds. Replacement costs exceed reported bird harassment costs on relatively large baitfish farms $(\geq 202 \mathrm{ha})$ when more than 65 great blue herons, 100 great egrets, and 220 little blue herons forage in ponds (Fig. 3). These hypothetical abundance estimates are less than average bird numbers reported during our survey.

\section{Discussion}

Based on Kushlan's (1978) model, little blue herons consume approximately 44 golden shiners (average mass assumed) each day to satisfy their food consumption needs. In comparison, great blue herons and great egrets consume approximately 30 goldfish and 24 baitfish each day, respectively. Our observations regarding the average number of fish captured by great blue herons are comparable to previous estimates of the average number of golden shiners consumed/feeding at Arkansas baitfish farms (Hoy 1994). The average number of golden shiners recovered from great egrets $(N=52$ collected birds) and little blue herons $(N=75) \mathrm{col}-$ lected at these farms in 1988 was 21 and four fish, respectively (Hoy 1994). Given that cultured baitfish are regularly stocked at high densities (e.g., 250,000-500,000 fish/ha; N. Stone, Extension Fisheries Specialist, University of Arkansas-Pine Bluff, personal communication), the number of fish captured by wading birds and their foraging efficiency may be positively influenced by prey densities (Draulans 1987) experienced at aquaculture facilities.

Relative to the foraging efficiency of great blue herons in marine environments $(0.28$ captures/strike [c/s]: Rodgers 1983), this species 
exhibits high efficiency at catfish aquaculture facilities (0.62 c/s; Ross 1994) and Arkansas baitfish farms $(0.6 \mathrm{c} / \mathrm{s}$, this study). Similarly, the foraging efficiency of great egrets at catfish $(0.58 \mathrm{c} / \mathrm{s}$; Ross 1994) and baitfish aquaculture facilities $(0.6 \mathrm{c} / \mathrm{s}$, this siudy $)$ is high relative to (hat obscrvod by Rôdgcrs $(1.983 ; 0.13 \mathrm{i} / \mathrm{s})$ and Dimalexis et al. (1997; $0.54 \mathrm{c} / \mathrm{s})$.

Our replacement-cost estimates may enable baitfish farm managers to make reasonable decisions regarding their bird damage management based on the foraging ecology, seasonal abundance, and associated impacts of wading birds near their farm. Additional research is needed to compare the overall monetary impact of bird depredation with resuitant baitfish production. Although Wooten and Werner (2004) recently documented the food habits of lesser scaup at Arkansas baitfish aquaculture facilities, additional research is also needed to estimate the cumulative impact of wading birds, double-crested cormorants, diving ducks, and pelicans to baitfish production.

The spatial relationships between breeding and foraging areas of wading birds have been previously documented (Gibbs 1991). We observed at least three heron and egret breeding colonies adjacent to Arkansas baitfish farms during aerial surveys in 1999. Following the 1999 breeding season, we also observed a high proportion of immature herons and egrets during our foraging observations and food habits investigation at baitfish farms. Thus, we suggest that early (i.e., prior to nesting season) dispersal of aggregated herons and egrets near Arkansas baitfish farms may minimize subseyuent impacts to fish production at adjacent aquaculture facilities.

\section{Acknowledgements}

We are grateful to Drs. Nathan Stone and Hugh Thomforde (Extension Fisheries Specialists, University of Arkansas--Pine Bluff) for summarizing trends in Arkansas baitfish production. We are also thankful for the support that we received from Arkansas baitfish producers during our study. We wish to thank Dr. S. A. Shwiff for consultations regarding resource economics, and L. Clark, C. Collins,
B. S. Dorr, A. Radomski, and M. E. Tobin for their review of an earlier draft of this manuscript.

\section{Literature Cited}

Carlander, K. D. 1969. Handbook of freshwater fishery biolugy, volume 1. The Iowa State University Press, Ames, Iowa, USA.

Dimalexis, A., M. Pyrovetsi, and S. Sgardelis. 1997. Foraging ecology of the grey heron (Ardea $\mathrm{Ci}$ nerea), great egret (Ardea alba) and little egret (Egretta gar-etta) in response to habitat, at 2 Greek wetlands. Colonial Waterbirds 20:261272.

Draulars, D. 1987. The effect of prey density on foraging behavior and success of adult and first year grey herons (Ardea cinerea). Journal of Animal Ecology 56:479-493.

Gibbs, J. P. 1991. Spatial relationships between nesting colonies and foraging areas of great blue herons. Auk 108:764-770.

Glahn, J. F. and K. E. Brugger. 1995. The impact of double-crested cormorants on the Mississippi Delta catfish industry: A bioenergetics model. Colonial Waterbirds 18 (Special Publication 1): $168-175$.

Glahn, J. F. and B. S. Dorr. 2002. Captive doublecrested cormorant P/alacrocorax auritus predation on channel catfish Ictalurus punctatus fingerlings and its influence on single-batch cropping production. Journal of the World Aquaculture Society 33:85-93.

Glahn, J. F. and A. R. Stickley, Jr. 1995. Wintering double-crested cormorants in the Delta region of Mississippi: Population levels and their impact on the catfish industry. Colonial Waterbirds 18 (Special Publication 1):137-142.

Glahn, J. F., P. J. Dixon. G. A. Littauer, and R. B. McCoy. 1995. Food habits of Double-crested Cormorants wintering in the Delta region of Mississippi. Colonial Waterbirds 18 (Special Publication 1): 158-167.

Glahn, J. F., B. S. Dorr, J. B. Harrel, and L. K'hoo. 2002. Foraging ecology and depredation management of great blue herons at Mississippi catfish farms. Juurnal of Wildlife Management 66: 194-201.

Glahn, J. F., B. Dorr, and M. E. Tobin. 2000. Captive great blue heron predation on farmed channel catfish fingerlings. North American Journal of Aquaculture 62:149-156.

Glahn, J. F., J. B. Harrel, and C. Vyles. 1999a. The diet of wintering double crested cormorants 
feeding at lakes in the southeastern United States. Colonial Waterbirds 21:446-452.

Glahn, J. F., D. S. Reinhold, and P. Smith. 1999b. Wading bird depredations on channel catfish Ictalurus punctatus in Northwest Mississippi. Journal of the World Aquaculture Society 30:107-114.

Harrel, J. B. and G. L. Stringer. 1997. Feeding habits of the alligator snapping turtle (Macroclemys temminckii) as indicated by teleosiean otoliths. Herpetological Review 28:185-187.

Hoy, M. D. 1994 . Depredations by herons and egrets at buitfish farms in Arkansas. Aquaculture Magazine 20(1):52-56.

Hoy, M., J. Jones, and A. Bivings. 1989. Economic impact and control of wading birds at Arkansas minnow ponds. Proceedings of the Eastern Wildife Damage Control Conference 4:109112.

King, D. T. and T. C. Michot. 2002. Distribution, abundance and habitat use of American White Pelicans in the delta region of Mississippi and along the western Gulf of Mexico Coast. Waterbirds 25:410-416.

King, D. T. and S. J. Werner. 2001. Daily activity budgets and population size of American White Pelicans wintering in south Louisiana and the Delta region of Mississippi. Waterbirds 24:250-254.

Kushlan, J. A. 1978. Feeding ecology of wading birds. Pages 249.297 in A. Sprunt IV, J. C.

Ogden, and S. Winckler, editors. Wading birds, Research report number 7. National Audubon Society, New York, New York, USA.
Palmer, R. S. 1976. Handbook of North American birds, volume 1. Yale University, New Haven, Connecticut, USA.

Rodgers, T. A. 1983. Foraging behavior of seven species of herons in Tampa Bay, Florida. Colonial Waterbirds 6:11-23.

Ross, P. G., II. 1994. Foraging ecology of wading birds at commercial aquaculture facilities in Alabama. Master's thesis. Auburn University, Auburn, Alabama, USA.

Stickley, A. R., Jr., J. F. Glahn, J. O. King. and D. T. King. 1995. Impact of great blue heron depredations on channel catfish farms. Journal of the World Aquaculture Society 26:194-199.

Stickley, A. R., G. L. Warrick, and J. F. Glahn. 1992. Impact of double-crested cormorant depredations at channel catfish farms. Journal of the World Aquaculture Society 23:192-198.

USDA. 2000. Aquaculture outlook. March 2000. LDP-AQS-11. U.S. Department of Agriculture. Economic Research Service, Washington, D.C.. USA.

Voisin, C. 1991. The herons of Europe. Academic Press. Inc., San Diego, California. USA.

Werner, S. J., M. E. Tobin, and P. B. Fioranelli. 2001. Great egret preference for catfish size classes. Waterbirds 24:381-385.

Wooten, D. E., and S. J. Werner. 2004. Food habits of lesser scaup Aythya affinis oceupying baitfish aquaculture ficilities in Arkansas. Journal of the World Aquaculture Society 35:70-77. 